\title{
"Uma festa de argentinos e brasileiros": diálogos sonoros entre Pixinguinha, Francisco Canaro e a Orquestra Típica Andreoni na década de 1920
}

\author{
"Uma festa de argentinos e brasileiros": musical \\ dialogues between Pixinguinha, Francisco Canaro \\ and Orquestra Típica Andreoni in the 1920's.
}

Pedro de Moura Aragão ${ }^{1}$

Universidade de Aveiro/UNIRIO pmaragao@ua.pt 


\section{Resumo}

Este artigo tem como foco o estudo de diálogos e trocas musicais entre Pixinguinha e músicos argentinos na década de 1920. Alinha-se com trabalhos recentes (BESSA, 2005; MENEZES BASTOS, 2005; COELHO, 2009) que têm procurado redimensionar a trajetória de Pixinguinha e seu papel na indústria fonográfica da primeira metade do século XX a partir de novos ângulos, colocando em relevo as múltiplas influências de um compositor e arranjador imerso em um sistema cosmopolita que exigia uma escuta diversificada e aberta a influências musicais estrangeiras. A primeira parte do artigo é focada na análise do tango La Brisa de Francisco Canaro, gravado pelo Grupo do Pixinguinha em 1922 e procura investigar evidências históricas que liguem os dois músicos neste período, além de realizar uma análise comparativa entre a gravação de Pixinguinha e outras gravações argentinas do mesmo ano. A segunda parte é dedicada ao estudo das relações entre Pixinguinha e a Orquestra Andreoni, orquestra que esteve no Rio de Janeiro no ano de 1928 e que realizou gravações de duas polcas e dois tangos argentinos do compositor brasileiro, além de apresentações em conjunto com a orquestra Os Batutas. Por meio destes dois estudos de caso, o artigo procura lançar novas luzes sobre gravações históricas pouco conhecidas que evidenciam processos de trânsito e de influências musicais múltiplas na carreira musical de Pixinguinha.

Palavras-chave: Tango. Música popular brasileira. Música Popular argentina.

\section{Abstract}

This paper is focused on the study of musical dialogues between Brazilian composer Pixinguinha and Argentinian musicians in the decade of 1920. It is based on recent research (BESSA, 2005; MENEZES BASTOS, 2005; COELHO, 2009) that tries to investigate Pixinguinha's career and contributions through a transnational perspective, stressing international musical influences in his music trajectory. The paper is organized in two parts. The first one is focused on the analysis of the tango La Brisa, written by Uruguaian/Argentinian composer Francisco Canaro. La Brisa was recorded in 1922 by Pixinguinha and his group, and my aim here is to stablish a comparative analysis between this specific recording and Argentinians recordings from the same period made by interpreters such as Carlos Gardel and Orquestra Típica Andreoni. The second part is dedicated to the study of Pixinguinha's relations with Orquestra Andreoni, a typical tango orchestra that had an intensive musical activity in Rio de Janeiro in 1928. Based on these two case-studies, this paper seeks to shed new lights on historical recordings that shows international influences and musical dialogues in Pixinguinha's musical career.

Key-words: Tango; Brazilian popular music; Argentinian popular music 


\section{Introdução}

Com mais de cinco décadas de atuação profissional (1920-1960), Alfredo da Rocha Vianna Jr. - por alcunha Pixinguinha (1897-1973) - teve papel fundamental como arranjador, compositor e intérprete no contexto da indústria fonográfica brasileira, atuando profusamente em diversas gravadoras, grupos orquestrais, programas de rádio e concertos pelo país e no exterior. Além disso, é usualmente apontado pela bibliografia especializada como tendo sido um dos responsáveis pela inserção da percussão do samba e de músicos negros - a começar por ele mesmo - no contexto da indústria fonográfica brasileira (ARAGÃO, 2001; CAZES 1998). Ainda que tenha sido amplamente reverenciado em vida por figuras como Lúcio Rangel e Almirante - que o tornaram em uma espécie de ícone da "velha guarda" e símbolo do que seria entendido como "autenticidade" da música popular brasileira -, os primeiros estudos sobre Pixinguinha datam somente da década de 1970. Trabalhos biográficos como os de Cabral (2007 [1978]) e Barbosa e Oliveira (2000 [1979]), se têm por um lado o mérito de serem pioneiros e de apresentarem uma ampla pesquisa sobre o tema, por outro contribuem para uma visão quase hagiográfica sobre o compositor, realizada a partir de um paradigma nacionalista característico de uma tendência característica dos estudos de música popular do período.

Nas últimas décadas, entretanto, estudos da área da Antropologia, Etnomusicologia e História Social têm procurado redimensionar a trajetória de Pixinguinha e seu papel na indústria fonográfica da primeira metade do século $X X$ a partir de novos ângulos. Para além de um viés que privilegia uma abordagem nacionalista, tais trabalhos tendem a enfatizar as múltiplas influências de um compositor e arranjador imerso em um sistema cosmopolita que exigia uma escuta diversificada e aberta a influências musicais estrangeiras. Tal cosmopolitismo era fruto de um sistema global de entretenimento (ERLMANN, 1996; OCHOA, 2003) que abrangia o teatro de revista - com companhias espanholas e portuguesas que transitavam continuamente entre os dois lados do Atlântico -, um vasto sistema de editoras de partituras que lançavam continuamente as novidades musicais da Europa e dos Estados Unidos (LEME, 2006) e uma incipiente, mas cada vez mais forte, indústria fonográfica que também reforçava este fluxo de gêneros musicais para além das fronteiras nacionais (ARAGÃO, 2016). Dessa forma, é significativo observar que a década de 1920 marca não apenas o início da trajetória profissional de Pixinguinha, como também seu período de maior abertura para influências cosmopolitas. Estas influências foram alvo de estudos por parte de Menezes Bastos (2005) -

\footnotetext{
1 Pedro Aragão é professor na Universidade do Rio de Janeiro (UNIRIO), Brasil, onde atua na graduação - lecionando prática de conjunto e História da Música Popular Brasileira - e na pós-graduação. Seus interesses de pesquisa incluem música popular brasileira, arquivos sonoros, relações entre indústria fonográfica e música popular e lusofonia. É autor do livro "Alexandre Gonçalves Pinto e 'O Choro',' que recebeu em 2012 o Prêmio Silvio Romero IPHAN - MINC (2 colocação) e o Prêmio Funarte de Produção Crítica em Música 2013. É organizador (com Bia Paes Leme, Paulo Aragão e Marcilio Lopes) dos livros "Pixinguinha, Inéditas e Redescobertas", "Pixinguinha: Outras Pautas" e "Carnaval de Pixinguinha", reunindo arranjos orquestrais desse compositor brasileiro para a rádio nas décadas de 1940 e 1950. Atuou como Professor Visitante na Universidade de Aveiro entre 2015 e 2016, onde desenvolveu pesquisa pós-doutoral sobre acervos sonoros em 78 rpm em Portugal e Brasil. Atualmente é Investigador Doutorado contratado na Universidade de Aveiro, onde coordena o projeto Liber|Sound: Práticas inovadoras de arquivamento para a libertação da memória sonora. Música gravada, experiências transcontinentais, comunidades conectadas.
} 
que analisou com profundidade a trajetória do grupo Os Oito Batutas em Paris no ano de 1922 -, de Coelho (2009) - que apresenta uma análise importante da trajetória dos Batutas em viagem à Argentina em 1923 e ao sul do país no ano de 1927 - e de Bessa - que analisou a escuta polifônica de Pixinguinha no Rio de Janeiro, onde seu ofício de arranjador já o obrigava a lidar com uma diversidade de gêneros musicais internacionais, ou, nas palavras do próprio compositor, a ouvir "um bocadinho de cada coisa" (BESSA, 2005).

O presente artigo filia-se a esta vertente de estudos, procurando lançar novas luzes sobre as relações pouco estudadas de Pixinguinha com músicos e gêneros musicais argentinos na década de 1920. A primeira parte é focada na análise da gravação do tango argentino La brisa, do compositor uruguaio (depois naturalizado argentino) Francisco Canaro, pelo Grupo do Pixinguinha em 1922. Procuro investigar evidências históricas que liguem os dois músicos neste período, além de realizar uma análise comparativa da gravação de Pixinguinha com outras gravações argentinas do mesmo ano. A segunda parte é dedicada ao estudo das relações entre Pixinguinha e a Orquestra Andreoni, grupo argentino que esteve no Rio de Janeiro no ano de 1928 e que realizou gravações de duas polcas e dois tangos argentinos do compositor brasileiro, além de apresentações em conjunto com a orquestra Os Batutas.

Este estudo integra ainda um projeto de pesquisa mais amplo, focado na catalogação musicológica da obra de Pixinguinha a partir de uma série de fontes documentais no Rio de Janeiro e em outras cidades do país. Uma breve contextualização deste projeto pode ser feita em poucas linhas: no ano de 2009 o autor deste artigo foi convidado a integrar uma equipe de pesquisadores e musicólogos ${ }^{2}$ que seria responsável pela editoração e revisão de arranjos de Pixinguinha presentes no acervo pessoal do compositor sob guarda do Instituto Moreira Salles do Rio de Janeiro e que posteriormente seriam publicados em três volumes (LEME, 2010; LEME et al., 2014a, 2014b). Dando prosseguimento a esta pesquisa, no ano de 2011 parte desta equipe ficou responsável pela curadoria do mesmo acervo, em um trabalho que envolveu a catalogação de mais de dez mil partituras manuscritas e editadas, bem como o estabelecimento de um catálogo crítico de obras de Pixinguinha que exigiu a consulta de diversos outros acervos musicais no Brasil, assim como busca de fontes variadas, como gravações, periódicos de época e material iconográfico. ${ }^{3}$

Foi justamente durante este processo que me deparei pela primeira vez com algumas das fontes primárias utilizadas como base para o presente artigo, como a foto com a apresentação da Orquestra dos Batutas e a Orquestra Andreoni em 1928 na boate Assirius do Rio de Janeiro, as gravações de tangos argentinos compostos por Pixinguinha pela mesma Orquestra Andreoni e a gravação do tango La Brisa pelo Grupo de Pixingui-

2 Coordenada por Beatriz Paes Leme, a equipe era formada por Marcílio Lopes, Pedro Aragão, Paulo Aragão, Luiz Flávio Alcofra, Ignez Perdigão, Caio Cesar e Jayme Vignoli.

3 Este trabalho de pesquisa foi realizado por uma equipe formada por Pedro Aragão, Paulo Aragão, Marcílio Lopes, Alexandre Dias e Beatriz Paes Leme e resultou na construção do site www.pixinguinha.com.br, que reúne todo o material organizado. Para além da publicação do site, este autor prevê a realização de uma série de artigos sobre o processo de pesquisa, do qual este é o primeiro. 
nha. A partir do contato com estas fontes primárias, uma série de perguntas pôde ser formulada: em que contexto tais gravações foram produzidas? Como se deu a relação entre músicos brasileiros e argentinos neste período e o que ensejou a realização destas gravações? De que forma tais registros podem lançar novas luzes para o entendimento de dinâmicas transnacionais nas práticas de música popular na década de 1920?

Este texto tenta responder a estas perguntas específicas valendo-se de pesquisa realizada em fontes primárias e acervos diversos, tais como a Hemeroteca Digital da $\mathrm{Bi}$ blioteca Nacional do Rio de Janeiro, a Discografia Brasileira em 78 rpm (SANTOS et al., 1982) e o próprio Acervo Pixinguinha no Instituto Moreira Salles. Finalmente, este artigo pretende ser ainda um contributo para uma série de estudos historicamente recentes sobre Pixinguinha que partem de novos paradigmas para o entendimento de sua obra e suas contribuições para o cenário da música no Brasil.

\section{Pixinguinha, Francisco Canaro e La Brisa}

A história das relações de Pixinguinha com músicos e gêneros musicais argentinos é cercada de lacunas e fatos históricos pouco explorados ainda hoje. Se a viagem do grupo Os oito Batutas em 1923 à Argentina foi minuciosamente analisada por Coelho (2009) em seus vários aspectos - desde a crítica dos jornais locais, passando pelo estudo do repertório e locais de apresentação do conjunto -, existe ainda uma série de encontros e apropriações musicais entre Pixinguinha e músicos argentinos ainda pouco estudada - antes e depois de 1923.

Um exemplo bastante sintomático destes trânsitos musicais é representado pelo tango argentino La Brisa, gravado em 1922 pelo "Grupo do Pechinginha" (disco Odeon n. 122162), tendo o próprio Pixinguinha em solo de flauta com acompanhamento de violão e banjo, conforme nos informa o rótulo do disco (Fig. 1). Trata-se de um disco bastante raro na Discografia Brasileira em 78 rpm - a ponto de seu registro não ter sido incluído na primeira edição impressa da discografia lançada pela FUNARTE na década de 1980 (SANTOS et al., 1982). Descoberto pelo pesquisador José Silas Xavier ${ }^{4}$ na década de 1990, a música foi posteriormente incluída na coleção Memórias Musicais (Biscoito Fino, 2002), organizada pelo também pesquisador e colecionador Humberto Francheschi.

\footnotetext{
4 Pesquisador e produtor musical, José Silas Xavier vem se dedicando ao estudo da vida e obra de Pixinguinha desde o final da década de 1970 , com uma coleção que envolve centenas de documentos, partituras, fotos e gravações raras de Pixinguinha. É produtor dos LPs Sarau brasileiro (Independente, 1979), Aos mestres com ternura (FENAB, 1987), Recordações de um sarau artístico (Independente, 1984), Chorando Callado (Eldorado, 1981), Ary Barroso - 90 anos (Transamérica, 1992), entre outros.
} 


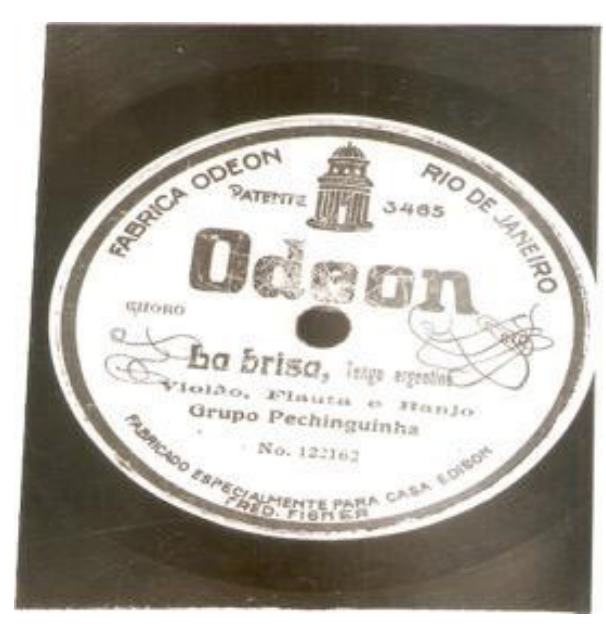

Fig. 1: Rótulo do disco La Brisa (Odeon 122162), lançado em 1922

Por ocasião da organização desta coleção - uma série de 12 CDs contendo gravações raras da Discografia Brasileira em 78 rpm -, fui convidado por Francheschi a fazer parte da equipe responsável pela seleção e redação de textos sobre as gravações. Naquela ocasião - motivado pela falta de maiores informações, já que o rótulo do disco não trazia qualquer informação de autoria -, Francheschi creditou a autoria da faixa a Pixinguinha, e meu próprio texto para o livreto que acompanhava a série de CDs (ARAGÃO, 2002) corroborava esta informação. No ano de 2015 , em meio ao trabalho de elaboração do catálogo crítico de obras de Pixinguinha (tal como explicado na introdução deste artigo), deparei-me novamente com esta música, da qual não consegui encontrar uma só partitura no Acervo Pixinguinha do Instituto Moreira Salles ou em qualquer outro acervo musical brasileiro consultado no âmbito daquele projeto de pesquisa. Nesta ocasião, entretanto, a pesquisa foi facilitada pelo desenvolvimento de meios de consulta digitais via internet - algo que era ainda pouco desenvolvido no ano de 2002, data de lançamento da coleção Memórias musicais. Em uma rápida consulta à rede mundial de computadores, foi possível identificar a música como sendo de autoria do compositor argentino Francisco Canaro (1888-1964), com letra de Juan Canaro. A pesquisa revelou pelo menos mais duas gravações deste tango no ano de 1922: por Carlos Gardel (Odeon 18056-B) e pela Orquestra Roberto Firpo (Disco Nacional 673-B). Além disso, foi possível localizar a partitura original do tango La brisa: 


\section{La Brisa}

EI Trio es upspirda en un potivo popular

POE E.YJ. CAHARO
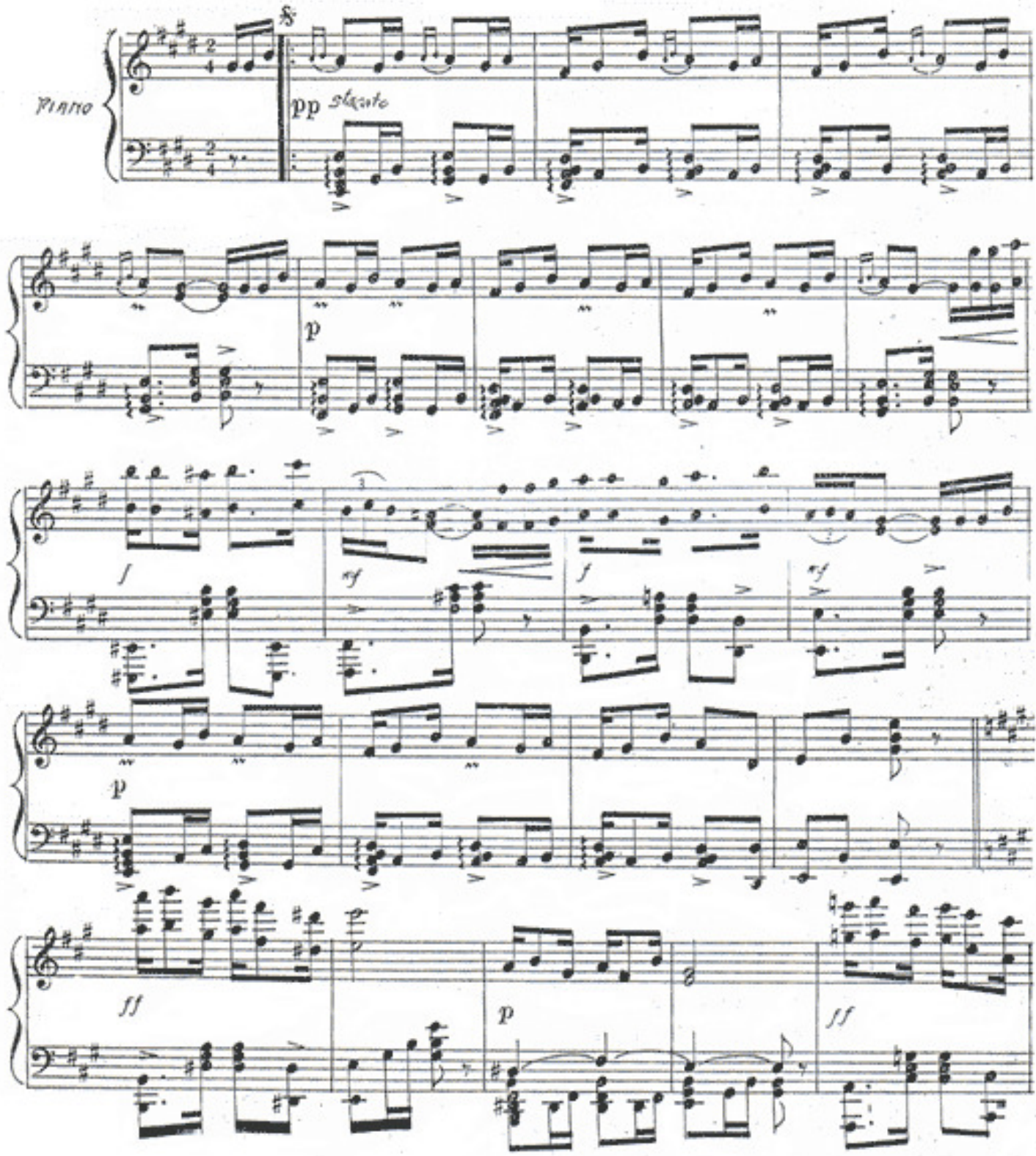

Fig. 2: Partitura do tango argentino La brisa por Francisco e J. Canaro. Fonte: Todo Tango ${ }^{5}$

Se por um lado o mistério de autoria de La brisa estava definitivamente solucionado, por outro lado outras questões surgiam: de que forma Pixinguinha teria tomado contato com esta música de Canaro? Teria havido algum encontro entre estes dois mú-

5 Disponivel em: www.todotango.com. Acesso em: 3 jan. 2018. 
sicos? Pixinguinha teria aprendido o tango La brisa por meio de partitura ou por meio de escuta aural - o famoso "tirar de ouvido", como usualmente denominado no ambiente da música popular? E, finalmente, uma outra questão crucial: o que teria levado Pixinguinha a realizar uma gravação tão diferente dos registros da mesma música realizados por grupos argentinos no mesmo período?

Ainda que as respostas a estas perguntas só possam ser em grande medida parciais, dada a exiguidade de fontes sobre o assunto, alguns indícios históricos podem nos guiar em algumas hipóteses. Para responder à questão sobre um possível contato entre Pixinguinha e Canaro, comecemos por discutir as relações deste último com o Brasil. A primeira vinda de Canaro ao país data de 1915, quando recebeu convite para gravar em Porto Alegre pelo selo Atlanta, segundo a biografia do próprio músico:

Em virtude de tal contrato com o senhor Améndola, embarcamos para Porto Alegre em um pequeño vapor de carga. [...] Me acompanharam Pedro Polito, bandonéon, e Leopoldo Thompson, contrabaixo. Os demais músicos, por razões de economia de gastos, foram contratados em Porto Alegre (CANARO, 1999, p. 134 , tradução minha). ${ }^{6}$

A partir daí, a popularidade das composições de Canaro no Brasil aumentaria progressivamente: é possível encontrar registros de partituras de seus tangos publicadas em revistas brasileiras do início da década de 1920, como O Malho e Jornal das Moças.

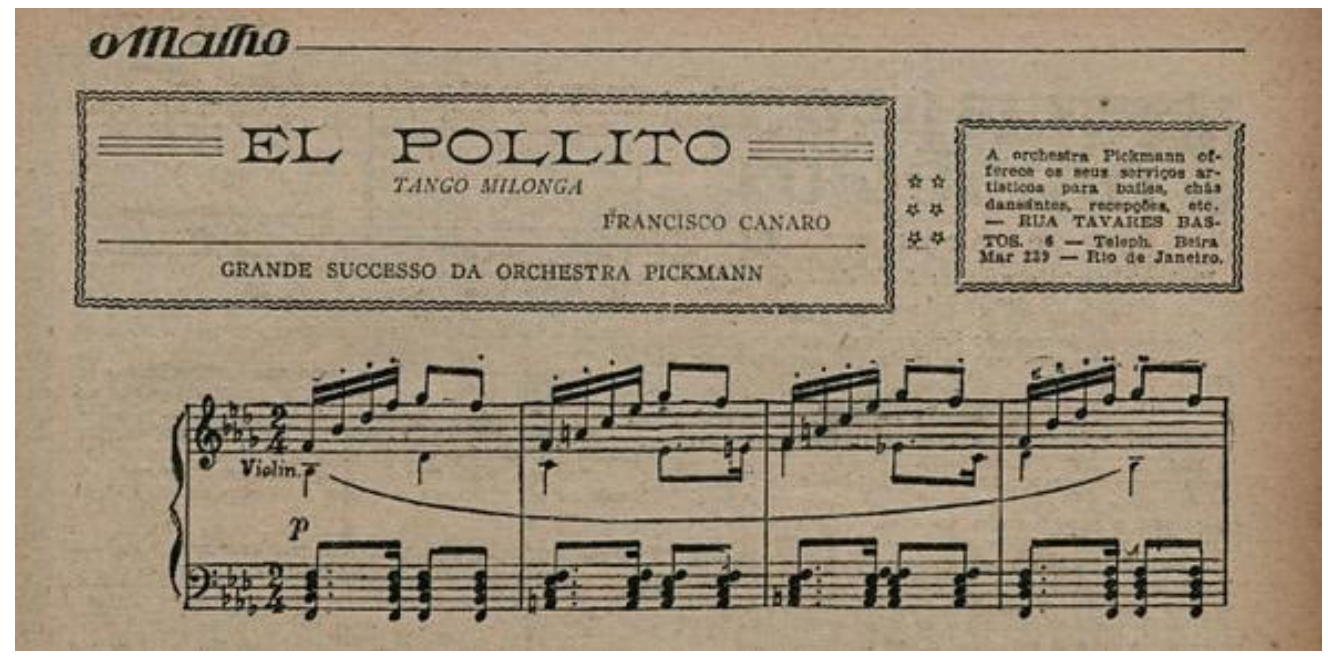

Fig. 3: El Pollito - Tango milonga de Francisco Canaro publicado em O Malho (edição 1039, agosto de 1922). Fonte: Hemeroteca Digital Brasileira.

Este anúncio também nos permite constatar a presença da música popular urbana argentina no repertório de orquestras de baile no Rio de Janeiro, como é o caso da Orquestra Pickmann, que anuncia seus serviços no pequeno quadro do canto superior

6 "Em virtud de tal contrato com el señor Améndola, nos enbarcamos para Porto Alegre en un pequeño vapor de carga. [...] Me acompañaron Pedro Polito, bandonéon, y Leopoldo Thompson, contrabajo; los demás músicos por razones de economía en los gastos, fueron contratados en Porto Alegre". 
direito do anúncio. Para além de partituras, é possível encontrar diversos anúncios de discos da Orquestra Típica Francisco Canaro ao longo da década de 1920 nas páginas dos principais periódicos brasileiros. ${ }^{7}$ Dessa forma, parece claro que a circulação de músicas de Canaro no Brasil neste período já fazia parte de uma rede que envolvia partituras editadas, performances ao vivo (por meio de orquestras de baile) e gravações. No que tange especificamente ao tango La Brisa, sabemos que recebeu gravações de Carlos Gardel e da Orquestra Firpo em 1922, o mesmo ano da gravação do Grupo de Pixinguinha, como detalharemos a seguir. Ainda que não tenha sido possível encontrar anúncios específicos da venda destes discos nas páginas dos periódicos da Hemeroteca Digital Brasileira, não parece ser improvável que tais discos tenham circulado no Brasil, dada a popularidade de um cantor como Carlos Gardel, por exemplo.

Sobre um possível encontro entre Pixinguinha e Francisco Canaro na década de 1920, existem também indícios sobre este tema no depoimento do primeiro ao Museu da Imagem e do Som em 1968, ainda que bastante contraditórios. Perguntado se teria participado de apresentações musicais na Exposição do Centenário da Independência em 1922 ao lado de Francisco Canaro, Pixinguinha diz a princípio não se lembrar. Logo depois, uma série de perguntas o colocam em contradição. Vale a pena transcrever o trecho do depoimento, editado pelo Museu da Imagem e do Som na década de 1970:

MIS: Segundo a lenda, você fez um tango de improviso e ofereceu a Francisco Canaro, depois que este havia the prestado uma grandiosa homenagem nessa Exposição. Você se lembra?

Pixinguinha: Eu não me lembro. Conheci muito o Francisco Canaro. Agora, se eu fiz não me lembro.

MIS: Por que é que você fez tangos com bandoneon e tudo?

Pixinguinha: Eu compus também músicas japonesas e outras. Você sabe, eu orquestrei umas três revistas e elas traziam aqueles quadros japoneses, turcos, etc. Eu tinha que escrever as músicas dentro do estilo de cada quadro. Devem estar lá na Sociedade de. Autores - a SBAT. O tango argentino também foi resultado disso. Agora, com o Francisco Canaro foi diferente. Eu fiquei muito satisfeito com ele, pois era um grande camarada. Durante uma conversa eu disse a ele que ia fazer um tango argentino em sua homenagem. E fiz.

MIS: Quer dizer que você já admite que fez um tango em homenagem a Francisco Canaro. Então há um fundo de verdade naquela história?

Pixinguinha: É possível que sim, mas... já se vão 46 anos, não é? (FERNANDES, 1970).

Como se vê, o depoimento é repleto de incongruências. Parece ter havido alguma fonte de tradição oral que apontava para um encontro entre Canaro e Pixinguinha na

\footnotetext{
7 Alguns exemplos são o jornal O País, que passa a publicar a partir de 1926 uma coluna dedicada aos lançamentos fonográficos intitulada "Discos e Máquinas Falantes", onde é possivel encontrar diversas críticas e anúncios de lançamentos de músicas pela Orquestra Típica Francisco Canaro, e o jornal Correio da Manhã, com a coluna "Música em discos", publicada a partir de 1928 e também repleta de anúncios de discos de Canaro.
} 
Exposição do Centenário, quando o último teria feito ao primeiro um "tango de improviso" - informação com áurea de "lenda", segundo o entrevistador. De fato, não foi possível identificar qualquer informação a este respeito em pesquisa realizada na Hemeroteca Digital da Biblioteca Nacional. ${ }^{8}$ O entrevistador do MIS também não nos fornece maiores informações sobre as fontes de onde esta informação teria surgido. Por outro lado, o próprio Pixinguinha se contradiz, a princípio dizendo não se lembrar de qualquer encontro com Canaro no centenário da independência e logo depois afirmando ter composto um tango em homenagem ao maestro argentino. Questionado sobre a incongruência, ele responde com um evasivo "é possível que sim, mas... já se vão 46 anos, não é?". O que parece haver de mais taxativo no depoimento de Pixinguinha é a afirmação de que ele teria de fato conhecido Canaro, a ponto de se tornar "um grande camarada". Em que circunstâncias este encontro se deu, entretanto, parece ser um ponto ainda obscuro.

Neste cipoal de informações dispersas, temos, entretanto, duas constatações historicamente comprovadas que nos devem servir de guia: a primeira é a que de fato Pixinguinha compôs pelo menos dois tangos argentinos, ambos gravados pela Orquestra Andreoni em 1928 - Fraternidade e Mis tristezas solo lloro, sob o selo Parlophon e números de série 12.829-A e 12.850-B, respectivamente. A segunda é a gravação de La Brisa pelo Grupo do Pixinguinha em 1922, único fato concreto que até o presente momento nos permite ligar o compositor brasileiro a Francisco Canaro. Analisaremos os tangos argentinos compostos por Pixinguinha na segunda seção deste artigo, quando focaremos com maior profundidade na estada da Orquestra Andreoni no Brasil. Por ora nos deteremos no tango La Brisa, por meio de uma breve análise comparativa entre as gravações do Grupo do Pixinguinha, de Carlos Gardel (Odeon 18056-B) e da Orquestra Firpo (Disco Nacional 673-B). ${ }^{9}$

Como dito anteriormente, as três gravações foram lançadas no mesmo ano de 1922, ainda que com orquestrações totalmente diferentes - violões e canto, no caso de Gardel; violinos, bandoneones e piano, no caso da Orquestra Firpo; e violão, banjo e flauta, no caso de Pixinguinha. Embora as três sigam rigorosamente o mesmo contorno melódico (que corresponde exatamente ao da partitura impressa), notam-se diferenças marcantes entre a inflexão rítmica entre as gravações argentinas e a gravação brasileira. Em primeiro lugar, as gravações da Orquestra Firpo e de Gardel claramente apresentam métrica quaternária, seguindo a tendência do tango platino da década de 1920 (Fig. 4 e 5), conforme se comprova não apenas pela inflexão melódica, mas também pelo caráter do acompanhamento:

\footnotetext{
8 Pesquisa realizada entre os dias 1 e 5 de dezembro de 2017. Utilizando o nome "Francisco Canaro" como palavra-chave, não foi possível encontrar nenhuma ocorrência que ligasse o nome do maestro uruguaio à Exposição do Centenário de 1922.

9 As gravações aqui analisadas estão disponíveis para audição nos seguintes links: https://www.youtube.com/watch?v=E3eE273PT9s (gravação de Carlos Gardel, Disco Odeon 18056-B), https://soundcloud.com/fandegardel/orquesta-roberto-firpo-la-brisa-1922 (Orquestra Firpo, Disco Nacional 673-B) e https://www.youtube.com/watch?v=Y88vFV-Cuv8 (Grupo do Pixinguinha, Disco Odeon n. 122162). Acesso em: 11 jul. 2008. A disponibilização dos links das gravações permite que o leitor tenha seus próprios elementos para confrontar com a análise que proponho neste artigo.
} 


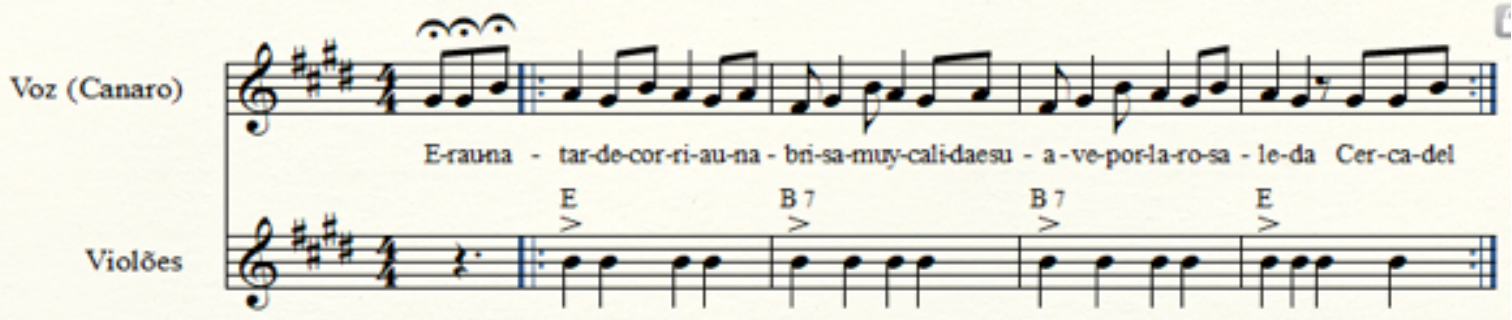

Fig. 4: La Brisa interpretada por Carlos Gardel - transcrição dos quatro primeiros compassos realizada a partir do disco Odeon 18056-B (transcrição do autor do artigo)

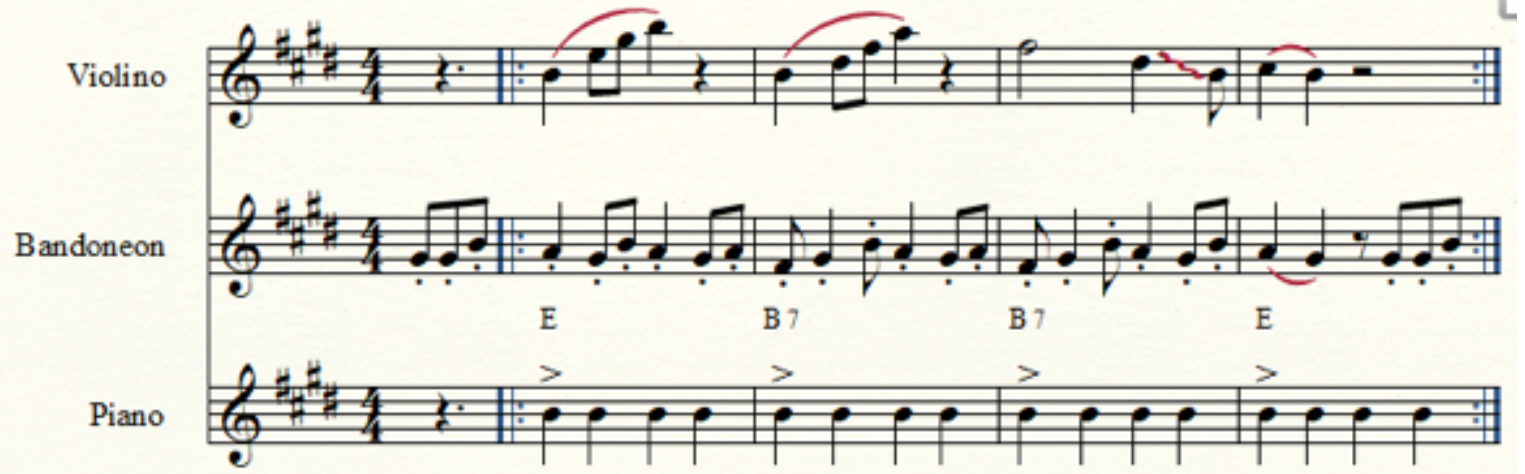

Fig. 5: La Brisa interpretada pela Orquestra Firpo - transcrição dos quatro primeiros compassos a partir da gravação do Disco Nacional 673-B (transcrição do autor do artigo)

À parte a presença de um violino que realiza um contraponto à melodia principal na gravação da Orquestra Firpo e o caráter de fermata que Gardel apresenta nas três primeiras notas da melodia (valorizando a letra da música), as inflexões dos solistas nas duas gravações são bastante parecidas, apresentando métrica nitidamente quaternária e uma articulação com caráter nitidamente staccato em toda a melodia. O acompanhamento é baseado em semínimas com acento no primeiro tempo do compasso, ao contrário da partitura original (ver Fig. 2), que apresenta na mão esquerda do piano figurações como colcheia + duas semicolcheias ou colcheia pontuada e semicolcheia - esta última figura tipicamente associada à habanera.

A gravação do Grupo do Pixinguinha, por seu turno, emprega métrica binária tanto na articulação da melodia quanto no caráter do acompanhamento. Mais do que uma simples questão de métrica, entretanto, é o próprio caráter da música que se transforma radicalmente. No que concerne à melodia, sua articulação foge totalmente ao padrão de staccato na melodia presente nas gravações argentinas e é substituída por um caráter legato - mesmo as colcheias internas das chamadas "síncopes características" (semicolcheia-colcheia-semicolcheia) são tocadas em tenuto -, o que faz com que toda a rigidez associada à execução do tango platino se dilua, em uma execução que remete à toada brasileira. Este processo é intensificado pelo estilo de acompanhamento: ao contrário do grupo de quatro semínimas vigorosamente articuladas na métrica quaternária das gravações argentinas, temos aqui o ritmo da habanera, calcado na figuração 
clássica de colcheia pontuada e semicolcheia - claramente articulado pelo banjo em quase toda a gravação -, sobreposto a um baixo de violão que improvisa contracantos na região grave.

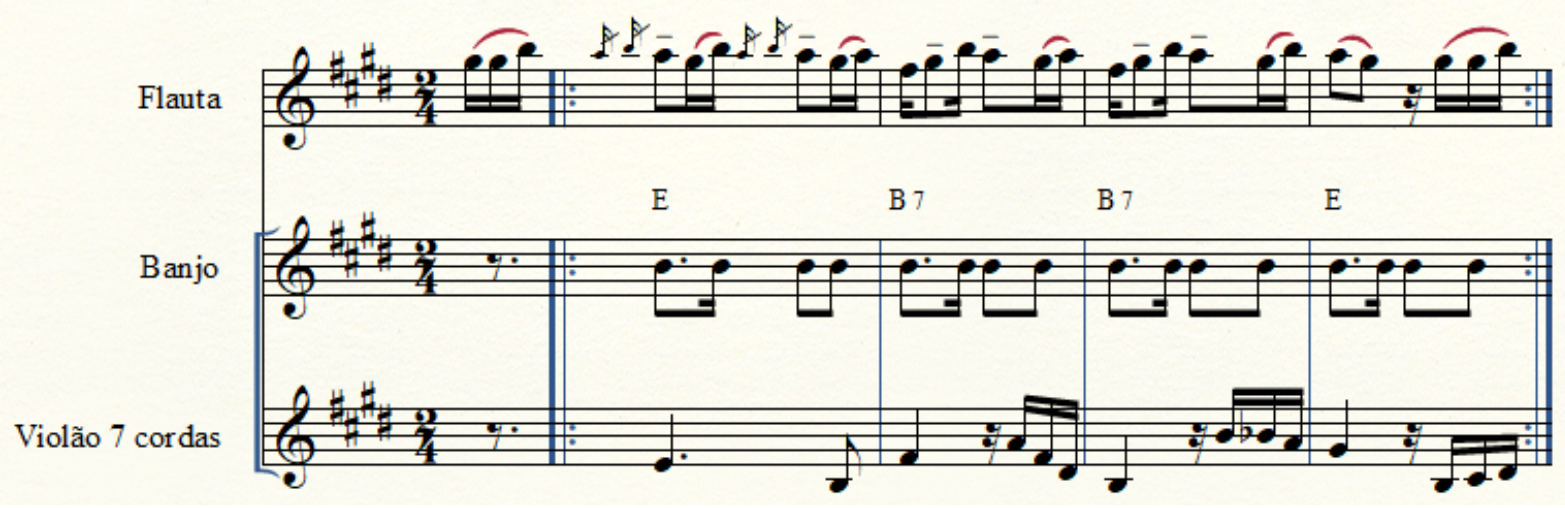

Fig. 6: La Brisa interpretada pelo Grupo do Pixinguinha - transcrição dos quatro primeiros compassos a partir da gravação do Disco Nacional 673-B (transcrição do autor do artigo)

Ora, é justamente esta fusão de rítmica de habanera com contracantos improvisados no baixo que será apontada por diversos autores como definição básica do chamado "tango brasileiro" (SANDRONI, 2001; ARAÚJO, 2007). Portanto, a comparação entre as gravações argentinas e a brasileira parece apontar claramente para duas realizações musicais distintas: por um lado, Gardel e a Orquestra Firpo realizam o que se convencionou chamar no Brasil de "tango platino": forte ênfase em staccatos e rígidas inflexões rítmicas na melodia (que estarão diretamente ligadas à prática da dança associada ao tango), acompanhamento firmemente calcado em semínimas em métrica quaternária, abandono da figura da habanera - uma das características deste tango platino, conforme apontado por autores como Salgán (2020, p. 22) e Sandroni (2001, p. 69). Por outro lado, a interpretação de Pixinguinha remete diretamente ao "tango brasileiro": ritmo de habanera no acompanhamento, contracantos improvisados no baixo e uma aparente "frouxidão" da articulação rítmica de melodia, que é a antítese da rigidez do tango platino e que remete ao "pequeno nada" ("petit rien") cunhado pelo compositor Darius Milhaud para caracterizar o tango tal como tocado no Brasil na década de 1910 (CAPORALETTI, 2012).

Em uma análise mais ampla, a comparação entre a gravação brasileira e as gravações argentinas nos aponta para duas questões importantes: a primeira relaciona-se com o grau de fluidez das práticas musicais nomeadas como "tango" na América Latina, e a segunda chama atenção para um momento histórico de transformação musical na própria estrutura do tango no contexto argentino. Como assinalam diversos autores (VEGA, 2016; GESUALDO, 1961; SANDRONI, 2001), a palavra "tango" serviu para designar, ao longo de todo o século XIX, bailes e práticas musicais associadas a ambientes afro-americanos. Para Vega, por exemplo, esta conotação poderia ser encontrada em diversas referências históricas tanto na Espanha quanto na América Latina: o Diccio- 
nario de la Real Academia, por exemplo, editado na Espanha em 1899, definia o termo "tango" como "Festa e baile de negros ou de gente do povo na América"10. Um ano depois, um decreto do alcaide de Havana estabelecia que: "Fica igualmente proibido que transitem pelas ruas desta cidade agrupamentos ou comparsas conhecidas pelo nome de tangos, cabildos e claves"11, referindo-se especificamente a agrupamentos de pessoas negras. Também em Montevidéu, no Uruguai, um decreto datado de 1816 determinava: "Se proíbem dentro da cidade os bailes conhecidos pelo nome de tangos, e só se permitem fora dos muros da cidade nas tardes dos dias de festas"12. Da mesma forma, diversos documentos históricos encontrados em países como Brasil, Argentina, Venezuela e Colômbia traziam a indicação do termo "tango" como sendo ligado "às coisas dos afro-americanos"13 (VEGA, 2016, p. 33-34).

Como afirma Sandroni (2001), o contexto de baile associado às esferas negras será paulatinamente apropriado pela indústria editorial de partituras da época, e o termo "tango" será utilizado para designar "músicas impressas sul e centro-americanas às quais se atribuía influência afro-americana" a partir da segunda metade do século XIX. De modo geral, tais partituras denominadas "tango" traziam fórmulas de acompanhamento baseadas no "ritmo de habanera" ou no chamado ritmo de tresillo $(3+3+2)$, apresentando melodias normalmente sincopadas, com acentuação nas segundas e quartas semicolcheias de cada tempo, em uma condição chamada por Sandroni de contrametricidade. É esta a característica geral de boa parte das partituras de tangos impressos tanto no Brasil quanto na Argentina durante as últimas décadas do século XIX até inícios do século XX. Compare-se, por exemplo, dois trechos dos tangos El Porteñito, de Angel Villoldo, e Bicyclette Club, de Ernesto Nazareth.
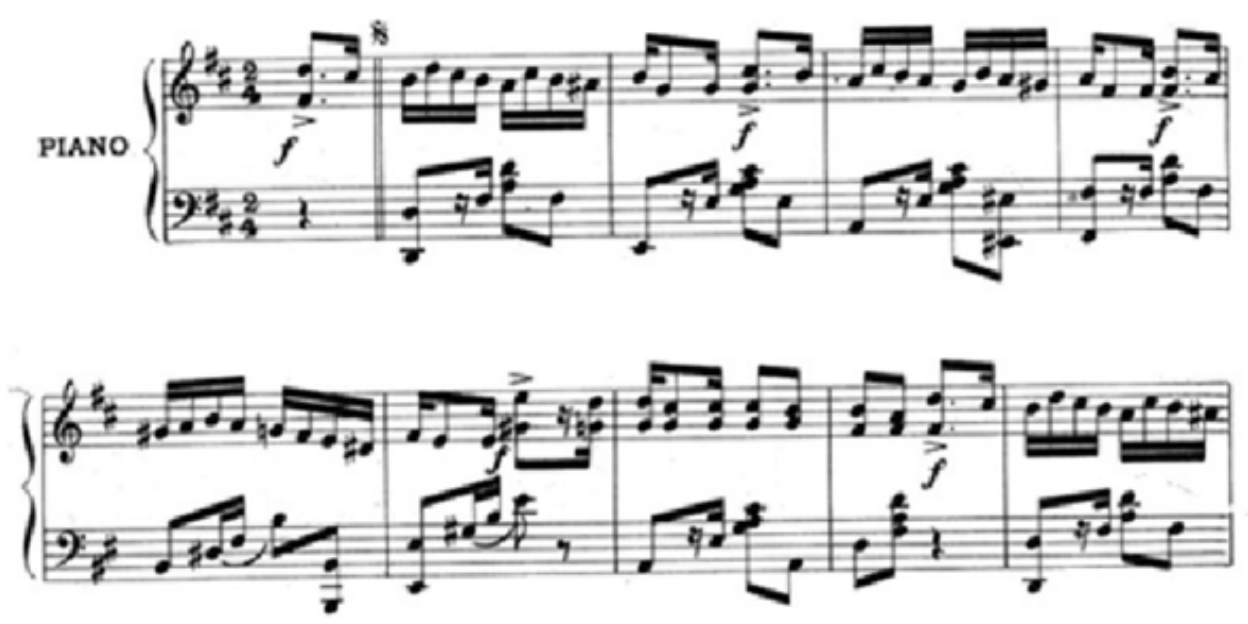

Fig. 7: Excerto de El Porteñito, tango criollo de Ángel Villoldo

\footnotetext{
10 "Fiesta y baile de negros o de gente del pueblo en América".

11 Queda igualmente prohibido que transiten por las calles de esta ciudad las agrupaciones o comparsas conocidas con el nombre de tangos, cabildos y claves".

12 "Se prohíben dentro de la ciudad los bailes conocidos por el nombre de tangos, y sólo se permiten a extramuros en las tardes de los días de fiesta".

13 "Las cosas de los afro-americanos".
} 

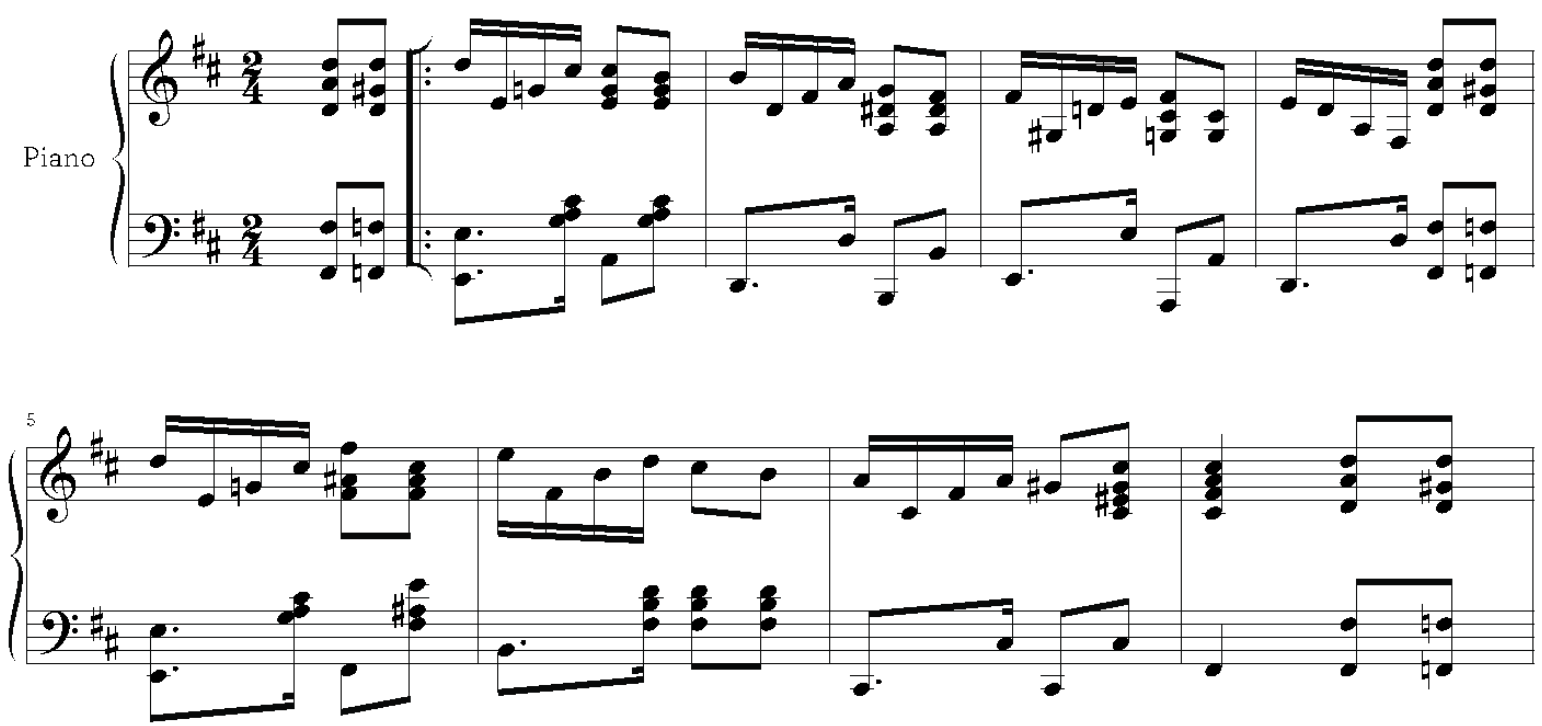

Fig. 8: Excerto de Bicyclette-Club, tango de Ernesto Nazareth

Estes dois tangos são praticamente do mesmo período: Bicyclette-Club foi publicado em 1899 no Rio de Janeiro pela editora Bevilaqcua, enquanto o tango El Portenito foi lançado no ano de $1901 \mathrm{em}$ Buenos Aires. ${ }^{14}$ Villoldo é usualmente identificado como um dos compositores da vieja guarda argentina (ROMERO, 2012) e sua obra é comumente associada aos primórdios do tango naquele país, representativa do que Salgán (2020) define como "primeira época do tango", onde este ainda seria marcado pela influência da habanera:

Devemos assinalar a diferença entre o tango do primeiro período, com acompanhamento habanera, e o tango em sua concepção mais atual, com o acompanhamento que comumente chamamos "em 4", ao qual se foi agregando a infinita variedade de figuras rítmicas que hoje conhecemos ${ }^{15}$ (SALGÁN, 2020, p. 19, tradução minha).

Como se vê, o autor aponta para uma mudança paradigmática na concepção do tango na Argentina a partir da década de 1920, relacionada com um "câmbio fundamental" que teria permitido ao gênero alcançar uma "jerarquia musical plena de lirismo" que o colocaria "entre las grandes creaciones de la musica del mundo" (SALGÁN, 2020, p. 22). Esta mudança fundamental estaria justamente ligada ao abandono da figura de acompanhamento da habanera pelo acompanhamento "en 4", tal como explica o autor:

14 Não foi possível encontrar, no âmbito desta pesquisa, a editora responsável pela publicação da primeira edição do tango em questão.

15 "Hemos que señalar la diferencia entre el tango de la primera época, com acompañamento de habanera y el tango em su concepción más actualizada, com el acompañamento que comúmente llamamos "en 4", al que se le fue agregando la infinita variedade de figuras rítmicas que hoy conocemos". 


\begin{abstract}
Abandonado o acompanhamento da habanera (que se escreve em 2/4) e quando o Tango começa a marcação rítmica "em 4", continuou a ser usual a utilização do mesmo compasso 2/4. Em seguida, considerando aquela numeração em 2/4, quando na realidade estavam sendo marcadas 4 colcheias, optou-se por relacionar a numeração do compasso com a referida marcação e o 2/4 foi substituído por 4/8. Atualmente a escrita do tango é feita em 4/4. Existe alguma diferença na execução quando tocamos um tango escrito em 2/4, 4/8 ou 4/4? Nenhuma. Obviamente falamos a partir do momento em que o acompanhamento Habanera não foi mais usado ${ }^{16}$ (SALGÁN, 2020, p. 22).
\end{abstract}

Em outras palavras, o abandono do acompanhamento da habanera e a transformação da métrica binária para a quaternária (ainda que muitas vezes o compasso 2/4 fosse mantido) marcaram, na visão de Salgán, o nascimento do tango argentino e sua completa diferenciação do tango "criollo" da vieja guarda, que ainda pertencia ao universo pan-americano da habanera. Esta filiação entre o tango "criollo" argentino e o tango brasileiro aparece tanto na comparação entre as músicas Bicyclette Club de Ernesto Nazareth e El Porteñito de Ángel Villoldo quanto na comparação entre a partitura original de La Brisa de Francisco Canaro (escrita em 2/4 e contendo acompanhamento "de habanera") e a gravação de Pixinguinha. Curiosamente, como me propus a mostrar, a execução do Grupo de Pixinguinha se aproxima mais da partitura original de Francisco Canaro do que as gravações de Carlos Gardel e da Orquestra Firpo. Estas últimas, como vimos, já sofrem influência do "câmbio fundamental", nas palavras de Salgán: a troca da métrica binária pela quaternária e o abandono definitivo da "figura de habanera" no acompanhamento. No início da década de 1920, entretanto, estas mudanças ainda estavam em processo, e a gravação de Pixinguinha parece indicar esta dubiedade de entendimentos: o rótulo do disco de sua gravação traz a inscrição "tango argentino" associada à música de Canaro, mas a execução filia-se à tradição do tango-habanera. No final da década de 1920, entretanto, a diferenciação entre o "tango argentino" e o "tango brasileiro" já será acentuadamente marcada, a ponto de o próprio Pixinguinha compor "tangos argentinos" utilizando métrica quaternária, conforme veremos no tópico a seguir.

\footnotetext{
16 "Abandonado ya el acompañamiento de la Habanera (que se escribe em 2/4) y cuando el Tango comienza la marcación rítmica que llammos "en cuatro", se siguió usando el numerar el compás del mismo em 2/4. Luego, considerando que numerar em 2/4, cuando em realidad se estaban marcando 4 corcheas, se decidió relacionar la numeración del compás com dicha marcación y se substituyó el 2/4 por el 4/8. Actualmente se enumera la escritura del tango em 4/4. Existe alguna diferencia em la ejecución cuando tocamos un tango escrito em 2/4, 4/8 o 4/4? Ninguma. Hablamos obviamente desde él momento em que yá no se usó el acompañamiento de Habanera."
} 


\section{Pixinguinha e a Orquestra Andreoni}

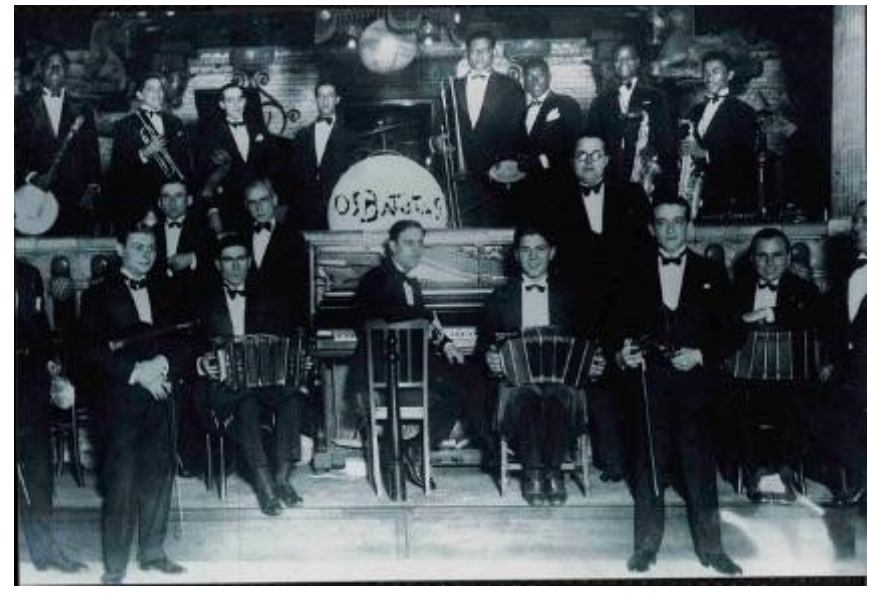

Fig. 9: Foto sem título. Acervo Sérgio Cabral - Museu da Imagem e do Som do Rio de Janeiro

A segunda parte deste artigo tem como ponto de partida a foto acima, parte integrante da coleção Sérgio Cabral no Museu da Imagem e do Som do Rio de Janeiro. Tal como a gravação do tango La Brisa, citada na primeira parte deste artigo, deparei-me com este documento no processo de pesquisa musicológica que redundou na catalogação e construção de um repositório digital do acervo Pixinguinha. Sem qualquer indicação de data ou de identificação dos elementos que a compõem ${ }^{17}$, a foto retrata claramente duas orquestras em um palco em dois planos. No plano superior, a inscrição "Os Batutas" no bumbo da bateria nos permite identificar imediatamente um dos mais célebres grupos musicais da década de 1920, que tinha em Pixinguinha um de seus principais componentes. Já o conjunto retratado no plano inferior não traz qualquer identificação visível: podemos apenas inferir, pela instrumentação típica de três bandoneones, dois violinos e piano, tratar-se de uma orquestra de tango argentino.

A utilização e análise de material iconográfico a partir do campo da historiografia foi objeto de estudo de Peter Burke (2004), um dos primeiros estudiosos a reconhecer o lugar relativamente desvalorizado que a imagem ocupa como "matéria-prima" da análise histórica, usualmente calcada no uso de fontes escritas. Em suas palavras, nas raras vezes em que o historiador se utiliza de imagens em publicações acadêmicas, estas são via de regra usadas para "ilustrar conclusões a que o autor já tinha chegado por outros meios" e quase nunca para "oferecer novas respostas ou suscitar novas questões" (BURKE, 2004, p. 9). É exatamente a partir deste último pressuposto que a foto do arquivo Sérgio Cabral será aqui utilizada. Ao representar um encontro entre um grupo instrumental em que Pixinguinha aparece como instrumentista e uma orquestra argentina, esta imagem pode ser utilizada para a formulação de uma série de questões: em que contexto ela foi tirada? Quais são exatamente os dois grupos retratados? Quem são os músicos que compõem estes grupos? Que tipo de repertórios e de trocas musicais

17 Nos catálogos do Museu da Imagem e do Som não existe qualquer indicação sobre a datação e os retratados na foto. Pesquisa realizada em junho de 2016. 
podem ser inferidas a partir deste encontro? De que maneiras a foto nos permite entender os processos de diálogos entre gêneros musicais brasileiros e argentinos?

Relacionando os elementos contidos na foto com a análise de outras fontes históricas, tais como notícias de jornal, fontes escritas e documentos sonoros, creio ser possível formular algumas hipóteses que sejam úteis para responder parcialmente às questões acima. Comecemos por analisar o próprio grupo de Pixinguinha: como já referido, a indicação "Os Batutas" no bombo da bateria nos fornece informações preciosas que permitem contextualizar o período histórico em que a foto foi tirada. Parece ser claro que a imagem não retrata o conjunto original "Os Oito batutas", que realizou a célebre viagem a Paris em 1922: como usualmente indicado nas biografias de Pixinguinha (CABRAL, 1978; BARBOSA; OLIVEIRA 2000), a formação original dos Oito Batutas era baseada na instrumentação típica de um regional de choro: flauta, violões, cavaquinho, bandolim e pandeiro. Da mesma forma, a literatura sobre o compositor é sempre pródiga em apontar para uma mudança de instrumentação a partir da volta da viagem a Paris, quando Pixinguinha teria passado a utilizar elementos típicos da jazz-band: saxofones, trombone, banjo e bateria, exatamente a instrumentação que aparece na foto. Assim, parece ser claro que a imagem retrata um conjunto formado depois do retorno do grupo da Europa, ou seja, seria um documento posterior ao ano de 1922. Além disso, uma análise da Discografia Brasileira em 78 rpm, disponibilizada de forma digital pelo Instituto Moreira Salles, ${ }^{18}$ nos permite apurar que entre os anos de 1928 e 1931 Pixinguinha realizou gravações com dois grupos instrumentais que herdaram a designação "Batutas". Entre 1928 e 1929, a chamada Orquestra Típica Oito Batutas realizou catorze registros para a gravadora Odeon: a audição destas faixas nos permite identificar uma formação instrumental que muito se aproxima da que é retratada na foto acima. Já entre 1931 e 1932, a Orquestra dos Batutas realizou oito registros fonográficos para a gravadora a Victor - também em formação orquestral que remete à instrumentação vista na foto. A pesquisa no mesmo repositório digital nos revela ainda que não há mais qualquer indicação de grupos de Pixinguinha com o nome de Batutas a partir de 1932. Desta forma, parece razoável supor que a foto foi tirada entre os anos de 1928 e 1932, os mesmos anos em que Pixinguinha realizava gravações comerciais com os dois grupos formados pela instrumentação típica do jazz-band e que ao mesmo tempo continham o nome Batutas.

No que concerne ao grupo argentino, uma análise de diversas fontes históricas do período nos aponta para a hipótese de tratar-se Orquestra Andreoni, dirigida pelo maestro argentino José Luiz Andreoni, então de passagem pelo Brasil para uma excursão na Europa. São vários os indícios que corroboram esta afirmação: em primeiro lugar, uma consulta ao repositório digital da Discografia Brasileira em 78 rpm nos mostra que a Orquestra Andreoni foi o único grupo argentino a realizar registros fonográficos no Brasil no ano de 1928. Além disso, dentre os registros realizados pela orquestra, significativamente encontram-se quatro composições de Pixinguinha, gravadas neste mesmo ano: os tangos argentinos Fraternidade e Mis tristezas solo lloro (que analisaremos adiante) e as polcas Pretensiosa e Encantadora, gravadas por uma dupla de bandone- 
ons, membros da orquestra. Finalmente, uma consulta à Hemeroteca Digital da Biblioteca Nacional do Rio de Janeiro nos permite ligar definitivamente o grupo ao evento retratado na imagem. As notícias encontradas na Hemeroteca nos permitem saber mais detalhes sobre o conjunto, seus componentes e sua trajetória no Brasil. A mais antiga delas é datada de 9 de junho de 1928 e foi publicada no jornal A Manhã:

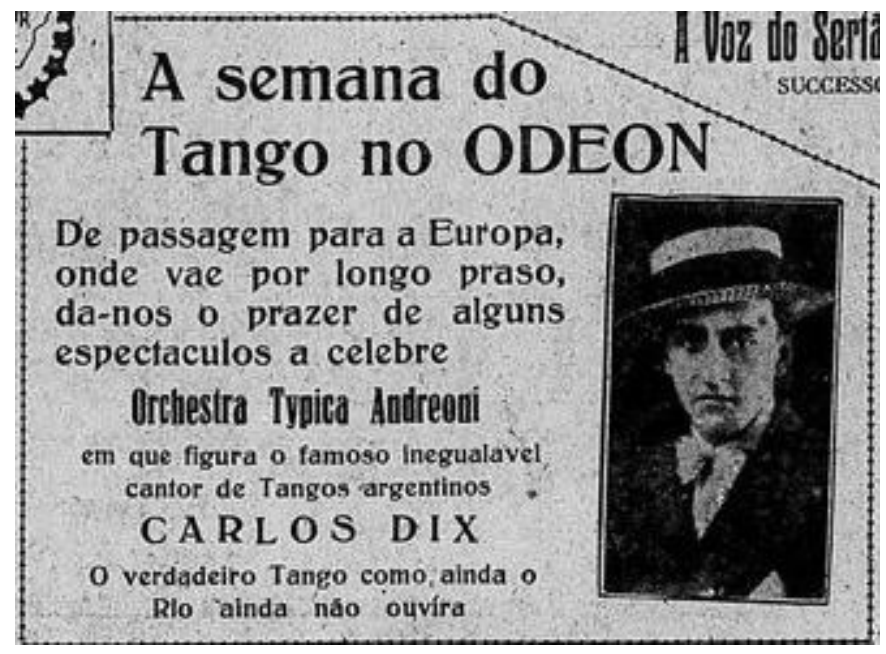

Fig. 10: Anúncio da apresentação da Orquestra Andreoni no Brasil de 9 de junho de 1928 no jornal A Manhã. Fonte: Hemeroteca Digital da Biblioteca Nacional do Rio de Janeiro.

A década de 1920 marca o sucesso internacional do tango e particularmente a consagração do gênero na Europa: neste sentido, vários conjuntos platinos saíam em excursão pelos principais centros europeus, tendo o Brasil como "rota de passagem", onde permaneciam para apresentações em diversas cidades. Como vemos no anúncio, o cantor Carlos Dix - pseudônimo de Carlos Alberto Martínez (1897-1969) - era também integrante da orquestra, destacando-se como compositor e letrista. A notícia seguinte, do mesmo jornal e publicada no dia 12 de junho, dá conta da estreia da Orquestra no Rio de Janeiro e nos fornece mais dados sobre seus integrantes. 


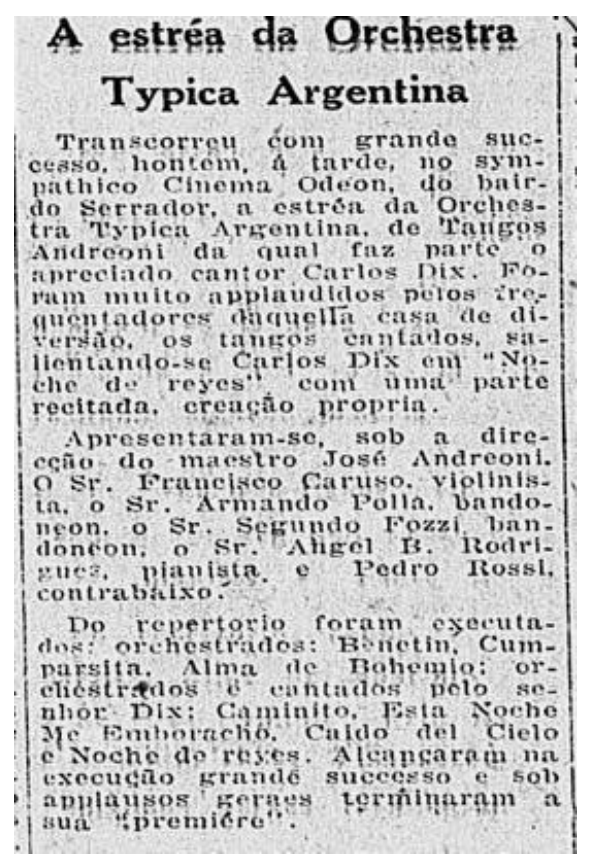

Fig. 11: Crítica da apresentação da Orquestra Andreoni no cinema Odeon do Rio de Janeiro, publicada no dia 12 de junho de 1928 no jornal A Manhã.

Fonte: Hemeroteca Digital da Biblioteca Nacional do Rio de Janeiro.

Como vemos, a orquestra era formada por José Andreoni (na verdade José Luiz Andreoni), maestro, Francisco Caruso (violino), Armando Polla e Segundo Fozzi (bandoneons), Angel B. Rodrigues (piano) e Pedro Rossi (contrabaixo). A formação é sem dúvida menor do que a que aparece na foto com Os Batutas (onde há dois violinistas e três bandoneonistas), mas não é impossível que a formação da Orquestra variasse a cada apresentação. Em todo caso, há mais um fator que liga a Orquestra Andreoni a Pixinguinha: José Luiz Andreoni é parceiro do compositor de Carinhoso em uma valsa intitulada Bianca, que será analisada adiante.

Finalmente, uma nova notícia publicada no dia 29 de agosto no mesmo jornal A Manhã parece estar diretamente ligada ao encontro musical entre argentinos e brasileiros ilustrado na foto do arquivo Sérgio Cabral.

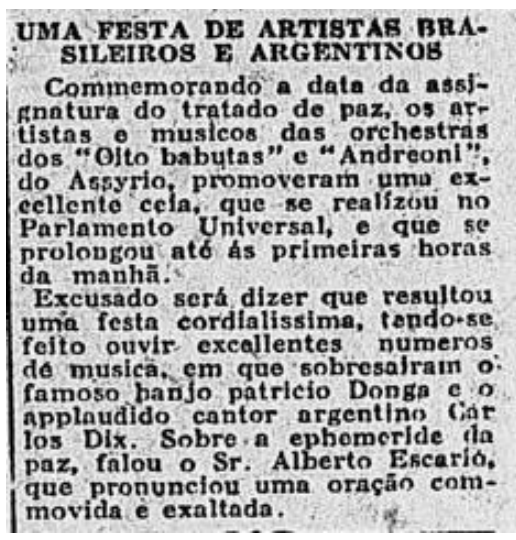

Fig. 12: Notícia da apresentação das orquestras Andreoni e Os Batutas publicada no dia 29 de agosto de 1928 no jornal A Manhã. Fonte: Hemeroteca Digital da Biblioteca Nacional do Rio de Janeiro. 
A "data da assinatura do tratado de paz", a que se refere a notícia, é uma referência ao Tratado do Rio de Janeiro, assinado nesta cidade no dia 27 de agosto de 1828 por Brasil, Argentina e Inglaterra, reconhecendo a independência da Província da Cisplatina, mais tarde Uruguai. Portanto, o centenário deste tratado foi celebrado pelo encontro das orquestras Andreoni e Os Batutas no dia 28 de agosto de 1928, em "uma festa de argentinos e brasileiros", conforme noticia o jornal. O palco do concerto parece ter sido a tradicional boate Assiryus, no Theatro Municipal do Rio de Janeiro, que se caracteriza pela exuberante arquitetura inspirada em motivos babilônicos e persas, reconhecível aliás na foto. Portanto, esta parece ser uma prova - senão conclusiva - bastante fidedigna de que a Orquestra Andreoni seria o conjunto argentino retratado com o Grupo de Pixinguinha na fotografia encontrada no arquivo Sérgio Cabral.

Para além da análise do registro fotográfico e da identificação dos grupos, entretanto, cumpre analisar o processo de trocas e diálogos musicais potencializados por este encontro, que demonstra mais uma vez o caráter dinâmico, cosmopolita e transnacional do ambiente da música popular da década de 1920. Neste sentido, não há dúvida de que a apresentação na boate Assirius foi na verdade o ponto de partida para uma série de interações musicais que acabaram por extrapolar os limites do palco, com reflexos em edições de partituras e gravações fonográficas do período. O corpus de músicas associadas a este encontro compreende uma diversidade estilística que passa pela linguagem tradicional do choro - as polcas Pretensiosa e Encantadora -, por duas incursões ao então "moderno" tango argentino, já com acompanhamento "em 4" (para usarmos a designação de Salgán) - representados pelos tangos Fraternidade e Mis tristezas solo lloro -, e finalmente por uma valsa cosmopolita com letra em espanhol de autoria de José Luiz Andreoni, intitulada Bianca.

Comecemos com a análise desta última: lançada em 1928 em partitura para piano pela Casa Vieira Machado do Rio de Janeiro, a valsa Bianca não teve nenhuma gravação no período de vida de Pixinguinha. ${ }^{19}$ Seu lançamento em partitura, entretanto, não passou despercebido pela revista PhonoArte, especializada na crítica musical do período, que classificou a música como "um tanto hespanholada, americanizada", transpirando "um pedantismo proveniente de seu próprio estilo indeciso". Ainda assim, segundo o crítico, a música seria classificada como "bem feita", com "harmonia assaz original" (CRÍTICA..., 1929).

19 A primeira gravação da valsa Bianca seria realizada apenas no ano de 2002 pelo cantor Marcelo Vianna, neto de Pixinguinha, no CD Teu nome é Pixinguinha (Biscoito Fino, 2002). 
- O popular Pexinguinha (Alfredo da Rocha Vianna), autor de tantos choros, maxixes e sam. bas de successo, dá-nos agora mais uma de suas valsas: Bianca, genero, ao qual o nosso conhecido autor parece ainda não se achar muito familiar. Bianca, é um tanto hespanholada, americanisada e transpira um "pedantismo" proveniente do seu proprio estylo indeciso... Embora tenhamos em conta a sua dedicatoria e o seu nome. Afora estes senões, a musica acha-se bem feita $\theta$ de harmonisação assaz original. Letra em hespanhol, de Andreoni, o conhecido dirigente da orchestra typica, ora entre nós.

A capa reproduz o mesmo desenho de Guevarra utilisado em União de Almas.

Fig. 13: Crítica da valsa Bianca, de Pixinguinha e Andreoni, lançada pela revista Phonoarte em 29/4/1929. Fonte: Acervo Pixinguinha do Instituto Moreira Salles. ${ }^{20}$

Uma análise da partitura nos permite entender parcialmente a percepção do crítico: Bianca tem uma linguagem harmônica bastante diferente das valsas tradicionais do período, a começar por sua introdução. Em vez de se iniciar com um aproveitamento temático do refrão ou do clímax da música, em uma harmonia que consolidasse a percepção tonal da mesma, como era praxe no período, Bianca apresenta uma introdução com uma harmonia cromática descendente, o que confere ao ouvinte uma sensação de instabilidade. Como se observa nos primeiros três primeiros compassos da Fig. 14, a música se inicia com uma sequência cromática de acordes de sétima da dominante, com o baixo na sétima: $\mathrm{Eb} / \mathrm{Db}-\mathrm{D} / \mathrm{C}-\mathrm{Db} / \mathrm{Cb}-\mathrm{C} / \mathrm{Bb}-\mathrm{B} / \mathrm{A}-\mathrm{Bb} / \mathrm{Ab}-\mathrm{A} / \mathrm{G}-\mathrm{Ab} / \mathrm{Gb}$, até finalmente se concluir na cadência $\mathrm{C} / \mathrm{Bb}$ e $\mathrm{F}$, que por sua vez introduzirá o acorde de $\mathrm{Bb}$ preparatório para a tonalidade da música: Eb. 


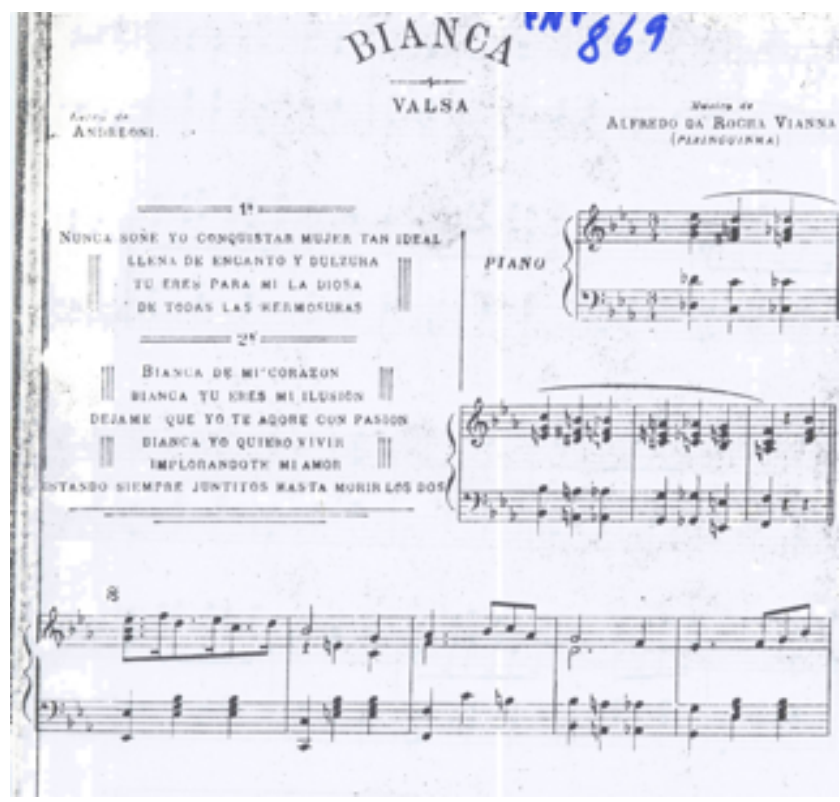

Fig. 14: Excerto da valsa Bianca, publicada em 1928 pela Casa Vieira Machado do Rio de Janeiro. Fonte: Acervo Pixinguinha do Instituto Moreira Salles.

Esta instabilidade tonal não se restringe à introdução, mas repete-se no próprio refrão da música. Conforme se observa nos compassos 1 a 5 e também nos compassos 9 a 13 da Fig. 15, a harmonização cromática descendente aparece novamente aqui em um ritmo harmônico que compreende a totalidade do compasso: $\mathrm{Eb} / \mathrm{Db}|\mathrm{D} / \mathrm{C}| \mathrm{Db} / \mathrm{Cb}$ | C/Bb | B/A.

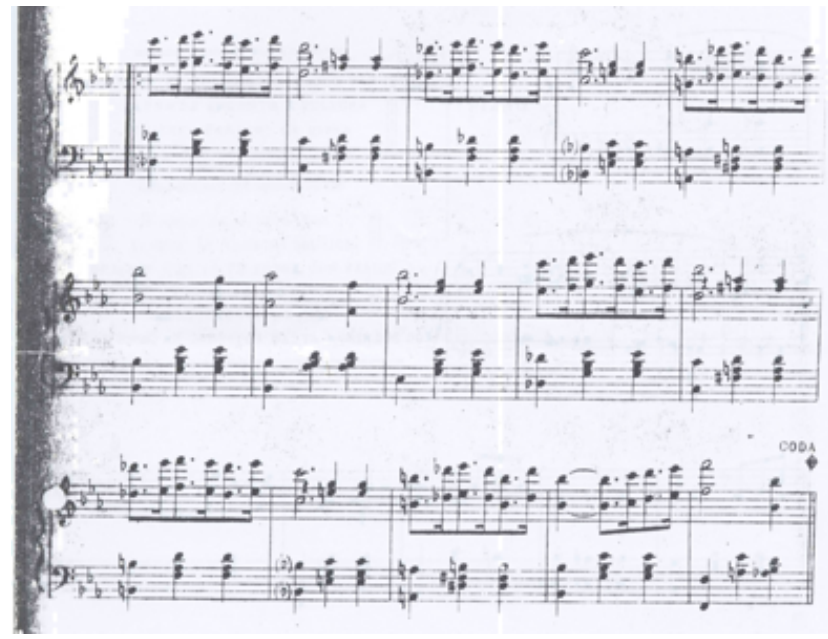

Fig. 15: Excerto da valsa Bianca, publicada em 1928 pela Casa Vieira Machado do Rio de Janeiro. Fonte: Acervo Pixinguinha do Instituto Moreira Salles.

Este tratamento harmônico tão pouco usual em valsas do período certamente colaborou para o estranhamento do crítico e para a classificação da música como pedante, "espanholizada" e "americanizada". O fato de ter recebido letra em espanhol e de ter sido dedicada a "uma garota de cabaré", segundo afirmou o próprio Pixinguinha em seu depoimento ao Museu da Imagem e do Som do Rio de Janeiro em 1968, reforçam o caráter cos- 
mopolita desta valsa - que musicalmente apresentava um universo diferente do se esperava de um típico compositor de "sambas, maxixes e choros de sucesso", nas palavras do crítico da PhonoArte. Não por acaso, neste mesmo ano de 1928, uma outra música de Pixinguinha seria igualmente tachada de "americanizada", por ter, na visão do mesmo crítico da revista PhonoArte, influência do jazz e do foxtrot: o clássico Carinhoso, lançado pela primeira vez em disco, ainda em versão instrumental, em dezembro daquele ano.

Os dois tangos argentinos gravados pela Orquestra Andreoni reforçam esta "escuta internacional" de Pixinguinha. Infelizmente o disco com o tango Fraternidade (Parlophon 12.829) permanece até hoje perdido, o que impossibilita a análise desta obra. Por sua vez, o tango Mis tristezas solo lloro lançado em disco Parlophon 12.850-B já apresenta uma concepção musical e um estilo de arranjo completamente diferente daquele apresentado na gravação do tango La Brisa em 1922. Aparentemente este tango jamais foi editado em partitura, e a análise que propomos é exclusivamente baseada na audição do registro fonográfico feito pela Orquestra Andreoni. ${ }^{21} \mathrm{~A}$ instrumentação apresentada na gravação - violinos e bandoneons com acompanhamento harmônico do piano - e a execução - com todos os rasgos dramáticos associados ao gênero - estão diretamente relacionadas ao universo do tango platino. Em termos formais, o tango é composto por duas partes de 16 compassos e uma pequena coda de quatro compassos, e, ao contrário do que acontece na linguagem tradicional do choro, as partes não se repetem. Desta forma, sua execução na gravação segue o seguinte esquema: $A B C C A B C C$, onde $A$ e $B$ designam respectivamente a primeira e a segunda parte, cada qual com 16 compassos, e $C$ designa a coda com quatro compassos, que é repetida duas vezes sempre. Para além do aspecto formal, cumpre ressaltar que, ao contrário do tango La Brisa, gravado em métrica binária por Pixinguinha em 1922, este tango mais recente já é executado em métrica quaternária (Fig. 16):

21 Disponível no website pixinguinha.com.br organizado pelo Instituto Moreira Salles no seguinte link: https://pixinguinha.com.br/resultado-busca/?keyword=mis+tristezas\&cpt=all. 


\title{
Mis tristezas solo lloro
}

\author{
tango argentino Pixinguinha
}
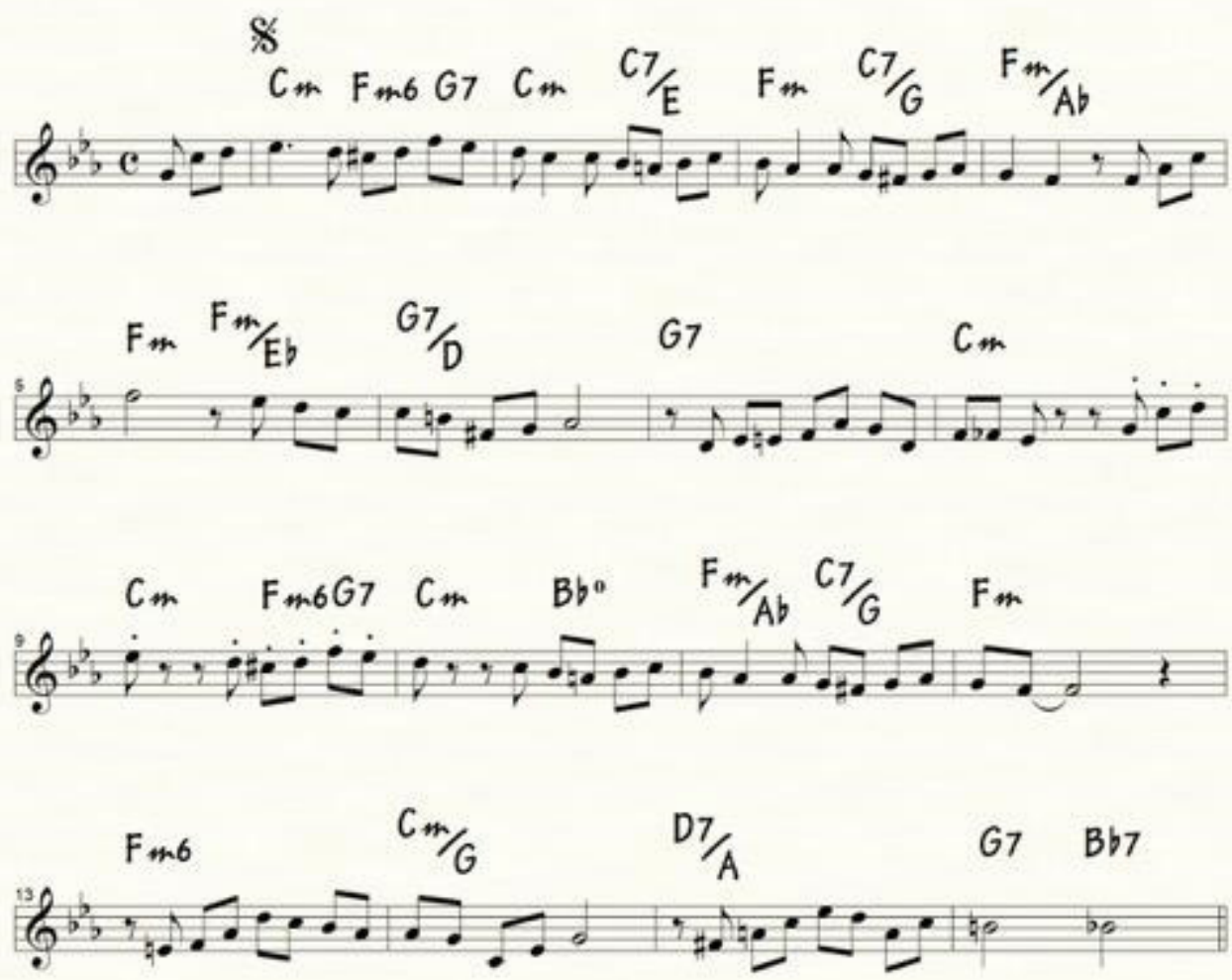

Fig. 16: Transcrição da primeira parte do tango Mis tristezas solo lloro de Pixinguinha a partir da gravação da Orquestra Andreoni (Parlophon 12.850-B). Transcrição de Paulo Aragão.

Ainda que o acompanhamento não seja simetricamente marcado em grupos uniformes de quatro semínimas e que apresente algumas variações rítmicas - que remetem a "la infinita variedad de figuras rítmicas" associadas ao tango platino nas palavras de Salgán (2020, p. 20) -, indubitavelmente a execução já demonstra um total distanciamento do universo de acompanhamento calcado na figura da habanera, característicos do tango criollo e em grande medida do tango brasileiro, tal como analisado na primeira parte deste artigo. Pelo contrário, o que se nota é uma execução já calcada no "cambio em 4", definidor de um novo paradigma do tango argentino. Outro fator a ser observado diz respeito à mescla com o próprio universo do choro: mesmo com a adoção da métrica quaternária e de toda a instrumentação típica do tango argentino, é possível se observar elementos fraseológicos e harmônicos que remetem diretamente à linguagem utilizada por Pixinguinha em algumas de suas mais conhecidas composições: o uso de contornos melódicos calcados em figuras de arpejos de acordes, tais como se observam nos compassos 13 a 15, é uma prova deste uso de um elemento típico da linguagem do choro neste tango argentino (Fig. 17). 


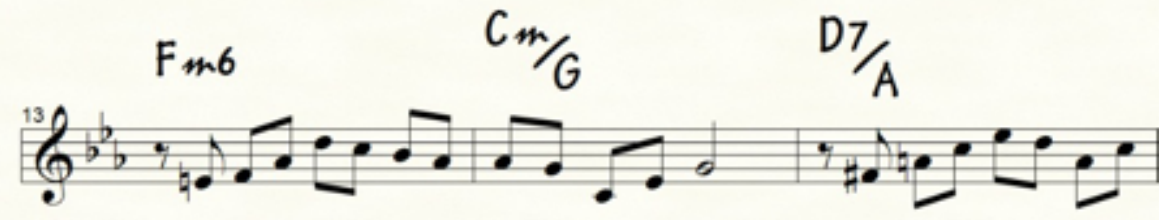

Fig. 17: Exemplo de contornos melódicos do choro no tango Mis tristezas solo lloro (compassos 13 a 15). Transcrição de Paulo Aragão.

\section{Conclusões}

Por meio da análise de dois momentos históricos distintos - os anos de 1922 e 1928 -, este artigo procurou revelar aspectos inéditos relativos a processos de diálogo e interação musical entre Pixinguinha e instrumentistas e compositores argentinos no início do século XX. Reforçando as abordagens propostas por trabalhos recentes que colocam ênfase no processo de escuta polifônica (BESSA, 2005) por parte de um compositor imerso em um sistema musical cosmopolita repleto de influências de gêneros transnacionais (MENEZES BASTOS, 2005; COELHO, 2009), busquei lançar novas luzes sobre gravações históricas pouco conhecidas que evidenciam estes processos de trânsito e de influências musicais múltiplas na carreira musical de Pixinguinha.

A análise da gravação do tango La Brisa, de Francisco Canaro, realizado pelo Grupo de Pixinguinha em 1922, e sua comparação com as gravações de Carlos Gardel e da Orquestra Firpo apontam para um período histórico de intensas transformações no tango. Procurei demonstrar a existência do universo de um tango "pan-americano", praticado em diferentes países e regiões da América do Sul, usualmente associado à influência afro-americana por folcloristas e musicólogos do período (VEGA, 2016; ANDRADE, 1989) e que fazia parte de uma ampla rede transnacional de partituras editadas. Como vimos, este tipo de tango seria conhecido como "tango criollo" na Argentina, por oposição ao "novo tango", que se consolida justamente na década de 1920 e que se caracterizaria pelo abandono da métrica binária e da figura rítmica de acompanhamento da habanera e pela adoção de métrica quaternária. A gravação do tango de Canaro pelo Grupo do Pixinguinha reflete uma filiação a este universo do tango "pan-americano", do qual tanto o tango brasileiro quanto o tango criollo faziam parte. Na comparação com as gravações de Carlos Gardel e da Orquestra Firpo, percebe-se que - paradoxalmente - Pixinguinha se aproxima mais da partitura original de Francisco Canaro e do universo da vieja guarda argentina do que os próprios intérpretes platinos. Ao mesmo tempo, a execução do Grupo do Pixinguinha estabelece uma clara ligação da composição de Canaro com o tango brasileiro por meio da figuração dos baixos do violão somada à figuração rítmica da habanera executada pelo banjo - o que configuraria uma das características deste gênero no Brasil.

Procurei também demonstrar a existência de uma significativa circulação de práticas musicais entre Argentina e Brasil ao longo da década de 1920, que se comprova por meio de evidências históricas, como anúncios de partituras bem como de discos de 
diversos compositores, intérpretes e orquestras argentinas à venda no Rio de Janeiro neste período. Esta ampla oferta de músicas argentinas se constituía como mais uma dentre as várias práticas sonoras transnacionais a que Pixinguinha teria acesso neste período e que fariam parte de sua "escuta polifônica", no dizer de Bessa (2005), influenciando sua trajetória musical, seus arranjos e composições. Este processo seria sem dúvida intensificado pelas viagens internacionais a Paris e à Argentina entre os anos de 1922 e 1923, quando Pixinguinha teria tido acesso ainda mais direto a uma grande gama de gêneros musicais cosmopolitas então em moda, tais como o tango argentino, o foxtrot, a chanson française, dentre outros. De retorno ao Brasil depois destas viagens, sua escuta absorverá cada vez mais estas influências que serão marcantes para a nova função para a qual o compositor se dedicará a partir do final da década de 1920: a de arranjador e maestro contratado pelas grandes holdings internacionais do disco fonográfico no Brasil, como a Victor e a Odeon.

É neste contexto que se dá o encontro, no ano de 1928, entre a Orquestra dos Batutas e a Orquestra Andreoni: a partir de uma fotografia encontrada no âmbito de um projeto de pesquisa mais amplo, procurei, na segunda parte deste artigo, estudar com maior profundidade a relação entre estas duas orquestras. Retorno ao documento fotográfico que abriu aquela seção para tecer algumas reflexões à guisa de conclusão. Em primeiro lugar, em consonância com o pensamento de Burke (2014), gostaria de chamar atenção para o lugar relativamente subvalorizado que a iconografia continua a apresentar no âmbito da etnomusicologia e dos estudos de música popular: em geral, fotografias e imagens são usualmente utilizadas por estudiosos destes campos apenas para corroborar o conhecimento adquirido por meio de fontes escritas e sonoras - documentos, partituras, registros fonográficos -, e não como ponto de partida para uma série de reflexões de pesquisa. No presente estudo de caso, procurei seguir um caminho totalmente inverso: a fotografia encontrada no acervo Sérgio Cabral foi o elemento detonador de uma série de perguntas que evidenciaram um rico processo de trocas musicais entre Pixinguinha e a Orquestra Andreoni, encontro que passou ao largo de toda a literatura acadêmica voltada para o compositor. Abro aqui um parêntese para relatar que minha primeira reação ao encontrar a fotografia foi a de lamentar que o repertório associado àquele encontro musical por ela retratado estivesse totalmente perdido. Entretanto, o recurso a fontes documentais complementares, tais como material hemerográfico e registros fonográficos da época, possibilitou recuperar, ao menos em parte, o universo musical daquele encontro. Esta constatação nos leva ao segundo ponto que gostaria de realçar: o de como aquele encontro musical transcendeu não apenas os limites de uma simples apresentação na boate Assirius do Rio de Janeiro, como também os próprios limites entre os dois planos do palco mostrados pela fotografia. Longe de ser simplesmente um encontro motivado apenas por uma data cívica - o centenário da independência do Uruguai - em que duas orquestras tocaram em palcos separados, procurei mostrar a existência de um profícuo diálogo musical. Tal diálogo passava pela incursão de músicos argentinos no universo do choro - evidenciado pelas gravações das duas polcas de Pixinguinha por membros da Orquestra Andreoni -, pela incursão do 
próprio Pixinguinha no universo do tango argentino - agora já definitivamente apartado da influência da habanera - e, finalmente, pela composição de Bianca, valsa cosmopolita e com harmonia pouco usual para a época, parceria entre Pixinguinha e o maestro argentino José Luiz Andreoni.

Mais do que encontros fortuitos entre músicos de nacionalidades diferentes, os dois estudos de caso aqui analisados apontam para uma ampla rede de influências e trânsitos musicais na América Latina, que foi historicamente subvalorizada por estudos de música popular no Brasil durante a segunda metade do século XX. No caso particular de Pixinguinha, o estudo destas redes de influências internacionais colabora para um reposicionamento do compositor como um elemento ativo no processo de diálogos e trocas musicais no continente sul-americano: sua escuta polifônica, que privilegiava "um bocadinho de cada coisa" (BESSA, 2005), ainda carece de um maior número de pesquisas que coloquem maior ênfase em tais aspectos transnacionais.

\section{Referências}

ANDRADE, Mário de. Dicionário musical brasileiro. Coordenação de Oneyda Alvarenga e Flávia Toni. Belo Horizonte: Itatiaia; Brasília: Ministério da Cultura; São Paulo: IEB区 USP, Edusp, 1989. (Coleção reconquista do Brasil, 2, série. v. 162).

ARAGÃO, Paulo. Pixinguinha e a gênese do arranjo brasileiro. Dissertação (Mestrado em Música) - Programa de Pós-Graduação em Música, UNIRIO, Rio de Janeiro, 2001.

ARAGÃO, Pedro. Pixinguinha. Encarte da Coleção Memórias Musicais. Rio de Janeiro: Sarapuí, Biscoito Fino, 2002.

ARAGÃO, Pedro. O acervo Pixinguinha no Instituto Moreira Salles. In: PAES LEME, Bia (org.). Pixinguinha na pauta: 36 arranjos para o programa "O Pessoal da Velha Guarda". São Paulo: Imprensa Oficial do Estado de São Paulo, 2010.

ARAGÃO, Pedro. Diálogos luso-brasileiros no Acervo José Moças da Universidade de Aveiro: um estudo exploratório das gravações mecânicas (1902-1927). Opus, v. 22, n. 2, p. 83-114, 2016.

ARAÚJO, Samuel (org.). César Guerra-Peixe: estudos de folclore e música popular urbana. Belo Horizonte: Editora da UFMG, 2007.

BARBOSA, Marília Trindade; OLIVEIRA, Arthur. Filho de Ogum Bexiguento. Rio de Janeiro: Gryphus, 2000. 
BESSA, Virgínia de Almeida. Um bocadinho de cada coisa: trajetória e obra de Pixinguinha. Dissertação (Mestrado em História Social) - FFLCH, USP, São Paulo, 2005.

BURKE, Peter. Testemunha ocular: história e imagem. Bauru: Educs, 2004.

CABRAL, Sérgio. Pixinguinha: vida e obra. Rio de Janeiro: FUNARTE, 2007.

CANARO, Francisco. Mis memorias: mis bodas de oro com el Tango. Buenos Aires: Corregidor, 1999.

CAPORALETTI, Vincenzo. Milhaud, le "Boeuf Sur Le Toit" e o paradigma audiotátil. In: CORREAA DO LAGO, Manuel Aranha (org.). O boi no telhado: Darius Milhaud e a música brasileira no modernismo francês. São Paulo: Instituto Moreira Salles, 2012. p. 229288.

CAZES, Henrique. Choro: do quintal ao Municipal. Rio de Janeiro: Editora 34, 1998.

COELHO, Luís Fernando Hering. Os músicos transeuntes: de palavras e coisas em torno de uns batutas. Tese (Doutorado em Antropologia Social) - Programa de PósGraduação em Antropologia, Universidade Federal de Santa Catarina, Florianópolis, 2009.

CRÍTICA da valsa Bianca. Revista PhonoArte, 29 abr. 1929.

Disponível em: www.pixinguinha.com.br.

ERLMANN, Veit. The Aesthetics of the Global Imagination: reflections on World Music in the 1990s. Public Culture, v. 8, n. 3, p. 467-489, 1996.

FERNANDES, Antonio Barroso (org.). As vozes desassombradas do museu. 1. ed. Rio de Janeiro: Secretaria de Eduação e Cultura, 1970.

GESUALDO, Vicente. Historia de la música en la Argentina. Buenos Aires: Beta, 1961.

LEME, Beatriz Paes. Pixinguinha na pauta: 36 arranjos para o programa O Pessoal da Velha Guarda. São Paulo: Imprensa Oficial do Estado de São Paulo, Instituto Moreira Salles, 2010.

LEME, Beatriz Paes; ARAGÃO, Paulo; ARAGÃO Pedro; LOPES, Marcílio. Pixinguinha Outras Pautas. São Paulo: SESC, Instituto Moreira Sales, 2014a.

LEME, Beatriz Paes; ARAGÃO, Paulo; ARAGÃO Pedro; LOPES, Marcílio. Carnaval de Pixinguinha. São Paulo: SESC, Instituto Moreira Sales, 2014b. 
LEME, Mônica Neves. "E saíram à luz...": as novas coleções de polcas, modinhas, lundus, etc. - Música popular e impressão musical no Rio de Janeiro (1820-1920). Tese (Doutorado em História Social) - Universidade Federal Fluminense, Niterói, 2006.

MENEZES BASTOS, Rafael de. Les Batutas, 1922: uma antropologia da noite parisiense. Revista Brasileira de Ciências Sociais, v. 20, n. 58, p. 177-213, 2005.

OCHOA, Ana Maria. Musicas locales en tiempos de globalización. Buenos Aires: Grupo Editorial Norma, 2003.

ROMERO, Avelino. Buenos Aires, História e Tango: crise, identidade e intertexto nas narrativas "tangueras". Tese (Doutorado em História). Universidade Federal Fluminense (UFF), 2012.

SALGÁN, Horacio. Curso de tango. Buenos Aires: Fuego Lento, 2020.

SANDRONI, Carlos. Feitiço Decente: transformações do samba no Rio de Janeiro (1917-1933). Rio de Janeiro: Zahar, 2001.

SANDRONI, Carlos. Rediscutindo gêneros no Brasil oitocentista: tangos e habaneras. In: ULHÔA, Martha; OCHOA, Ana Maria (org.). Música Popular na América Latina: Pontos de Escuta. Porto Alegre: UFRGS Editora, 2005. p. 175-193.

SANTOS, Alcindo; BARBALHO, Grácio; AZEVEDO, Miguel Ângelo; SEVERIANO, Jairo. Discografia brasileira em 78 rpm: 1902-1964. Rio de Janeiro: FUNARTE, 1982.

VEGA, Carlos. Estudios para los orígenes del tango argentino. Buenos Aires: Universidad Católica Argentina, Instituto de Investigación Musicológica "Carlos Vega", 2016. Disponível em: http://bibliotecadigital.uca.edu.ar/repositorio/libros/origenes-tango-argentino-vega.pdf. 